\title{
A systematic retrieval of international competitiveness literature: a bibliometric study
}

\author{
Magdalena Olczyk ${ }^{1}$
}

Received: 15 December 2015/Revised: 29 June 2016/ Accepted: 15 July 2016/

Published online: 5 August 2016

(C) The Author(s) 2016. This article is published with open access at Springerlink.com

\begin{abstract}
Over the last three decades there has been growing interest in international competitiveness research. However, as evidenced by the academic literature, there is a lack of systematic chronological studies synthesizing how this field has evolved over time. The main aim of this paper is to consolidate the state of the art of academic research on international competitiveness in the discipline of economics by using a new method: a bibliometric study of the economics literature published over the past 70 years. Citation data is collected from Web of Science, Scopus and Google Scholar, and it is analysed using HistCite, Pajek and VOSviewer software. Using bibliometric indicators, network citation analysis, key-routes main path methodology and term co-occurrence analysis, it investigates the growth pattern of the international competitiveness literature, identifies the core journals and authors, the main paths of knowledge diffusion and the key research domains in the international competitiveness literature. The results of the analysis show that studies on international competitiveness have been and still are important and popular in economics. International competitiveness concepts come from models of competition and are not strongly connected with classical theories of international trade. Publications by Krugman, Fagerber and Balassa have made the greatest contributions to the development of international competitiveness studies, but only Krugman's works have been significant in terms of knowledge diffusion. International competitiveness mostly refers to international trade/export performance and to the impacts of cost, price, exchange rates, income and FDI. However, in the last decade the relationships between trade flows and technology, liberalization processes, environmental regulations, location, education/human capital and productivity have become key topics in international competitiveness studies.
\end{abstract}

Magdalena Olczyk

Magdalena.Olczyk@zie.pg.gda.pl

1 Department of Economics, Gdansk University of Technology, Narutowicza 11/12, 80-233 Gdańsk, Poland 
Keywords International competitiveness $\cdot$ Bibliometrics $\cdot$ Historiography $\cdot$ Citation network $\cdot$ Term co-occurrence $\cdot$ Key-routes main path analysis

JEL Classification B2 $\cdot \mathrm{C} 02 \cdot \mathrm{F} 40$

\section{Introduction}

International competitiveness is a key topic of interest to all, including managers, politicians and academics, especially as the globalization process is changing the competitive landscape. The popularity of the international competitiveness concept is clearly demonstrated by the more than 6.5 million results generated by a Google search and by the increasing interest around the issue of competitiveness rankings, especially at the country level (Hassett 2012). International competitiveness has also become a central objective of national economic policies and strategies.

Despite its high popularity, international competitiveness has been described as one of the most misunderstood concepts, especially in economics, with even scepticism about the term itself being expressed by some academics (Krugman 1994; De Grauwe 2010). There are four main reasons why we do not have a widely accepted definition of international competiveness, not to mention a generally accepted theory of the subject (Lachmann 2001).

First, the concept of international competitiveness is very broad. It can be examined at different levels: those of the product, firm, industry or sector, region, nation, commercial block, or as an aspect of global trade, and there is a close connection or relationship between all these levels of competitiveness (Anca 2008). It is a concept the understanding of which comes from different disciples, not only from economics but also from management, history, politics and culture. Even in the discipline of economics, the theoretical background to international competitiveness is related to various theories, i.e. the classical and neoclassical Keynesian theories, development economics theory, new growth theory and new trade theory. Additionally, due to globalization and liberalization processes the boundaries between domestic and international markets have faded, leading to a disappearance of the distinction between national and international competitiveness.

Second, misunderstanding of the international competitiveness concept reflects the fact that its key insights are powerfully contrary to what our intuition leads us to expect (ITS Global Raport 2008). The idea of international competitiveness understood as the capacity to successfully compete with rivals in international markets is only properly understood as it applies at the microeconomic level. While companies compete with others for resources and market shares, and in the case of failure some have to go out of business, economies do not compete for resources, which are often fixed in space and time, and they never go bankrupt in an economic sense (Krugman 1994). These different ways of competing, depending on the level of discussion, imply different ways of measuring competitiveness for companies, sectors and economies, which makes the concept of international competitiveness more and more misunderstood. 
Third, we can only find a few statements in the literature which are widely accepted amongst academics dealing with international competitiveness issues. These argue that international competitiveness comes from competition (Porter 1990). Moreover, competitiveness has been delineated by many researchers as a relative and multidimensional concept (Spence and Hazard 1988; Flanagan et al. 2007) and is generally considered synonymous with success and economic strength in the global environment (Srivastava et al. 2006). Some economists also agree that the roots of international competitiveness studies can be found in classical international trade theories.

Finally, debate about international competitiveness is based on a multitude of concepts, often without any explicit theoretical foundation. Reviews of the international competitiveness literature are very rare (Chaudhuri and Ray 1997; Banwet et al. 2002; Bhawsar and Chattopadhyay 2015). They all underline the multitude of definitions, focus on different measurements and theoretical models, but always describe international competitiveness as an elusive concept. They only propose an integrated and eclectic approach, combining different schools of thought and multiple measurements as the most suitable way to study international competitiveness issues.

The existing reviews of international competitiveness literature have one major drawback. They do not synthesize the existing literature and do not show the relationship between the different understandings of the concept. Even the authors of the World Competitiveness Ranking highlight the difficulties in fitting competitiveness measurements to the conceptual framework of competitiveness and the absence of causality among the structural components of the competitiveness ranking (Bris and Caballero 2015). We still know nothing about the core publications or authors in the international competitiveness literature which may be the basis of the origin of international competitiveness theory. What is needed is the use of a new approach, a new methodology to investigate the competitiveness literature. According to Bofinger (1995) and Mitschke (2008), the concept of international competitiveness is probably located within an interface region in the scientific network, and the traditional approach of literature analysis is insufficient.

Consequently, the aim of the present paper is to fill this research gap by using an absolutely new approach in this research area: bibliometric methods. According to the best knowledge of the author, an analysis of the literature on international competitiveness using bibliometric methods has not yet been carried out. This paper has the main aim of consolidating the state of the art of academic research on international competitiveness by making a bibliometric study of the literature published over the past 70 years, but only in the discipline of economics. Citation data is collected from Web of Science, Scopus and Google Scholar, and is analysed using HistCite, VOSviewer and Pajek software. The main purpose is to accomplish the following objectives: to investigate the growth pattern of the international competitiveness literature, and to identify the core journals, authors and key international competitiveness research domains and the relationship between them. Knowledge diffusion in the international competitiveness literature will also be examined.

The rest of the paper is structured as follows. The next section reviews the literature on the international competitiveness concept. Section 3 presents the data and methodology. Section 4 provides the results of the estimations. Finally, Sect. 5 consists of discussion and concluding remarks. 


\section{Literature review}

The discussion on international competitiveness and the search for its determinants began in the 1970s and have dominated research in the area of international economics. Until the 1970 s, international trade theory had been dominated by the theory of competitive advantage, which assumes that a country can enhance competitive advantage if it specialises in production of those products that it can produce relatively more efficiently than other countries (Krugman and Obstfeld 2003). However, since World War II a growing amount of economic activity has consisted in massive two-way trade in similar industries and can no longer be explained by competitive advantage theory. This trade is primarily driven by advantages resulting from economies of scale (Smit 2010). In the late 1970s new models of monopolistic competition were developed (Krugman 1990). The new trade theories assumed that at the level of intra-industry trade economies of scale could explain trade flows of differentiated products. However, both theories assumed that advantage comes through specialisation. Later, the focus of scholars shifted towards oligopolistic competition, where economies of scale at the level of the firm are sufficient to limit the number of competitors (Krugman 1992). These resulted in the development of trade models that assumed an oligopolistic market structure (Krugman and Obstfeld 2003). These models imply that even without comparative advantage two-way trade in identical products still occurs and can still be mutually beneficial in industries where internal economies of scale are important (Krugman and Obstfeld 2003).

The theories of monopolistic and oligopolistic competition do not explain where the actual production should be located (Smit 2010). Porter (1990) proposed a 'new theory' that explains location advantages and thus the competitive advantage of nations. Porter identifies four classes of country attributes that determine national competitive advantage: factor conditions; demand conditions; related and supporting industries; and company strategy, structure and rivalry. He also indicates two other factors-government policy and chance (exogenous shocks) - that support the system of national competiveness but do not create it (Porter 1990). A key feature of Porter's proposal is that it integrates many different theories into the one concept, i.e. 'factor conditions' relate to classical/neoclassical economics, 'demand conditions' are connected to product cycle theory and Rostow growth theory, 'related and supporting companies' derives from polarization theory and Marshall's industrial districts, and 'firm strategy, structure and rivalry' refer to the works of Schumpeter. Although the diamond model has been widely applied to studying the international competitiveness of different countries, it has met with some criticism. According to Smit (2010), the weak aspects of Porter's model have been pointed out both by scholars of management (Dunning 1993) and economics (Boltho 1996). Management experts accuse Porter of not considering multinational activities in his model, so Dunning (1993) extended Porter's original model by adding the following variables: foreign direct investment, government policies and pro-competitive policies. Next, Cho and Moon extended Porter's original model by including four additional human variables: workers, politicians and bureaucrats, entrepreneurs, and professionals (Cho et al. 2008). In turn, economists indicate a lack of ex ante 
prediction ability as a weak point of the model and the weak connection of the Porter model with international trade theories.

Nevertheless, the diamond model was a breakthrough in the study of international competitiveness due to Porter and his followers' complex approach to analysis of the subject. It opened a discussion about the determinants and indicators of international competitiveness and became a basis for the creation of two leading indices of competitiveness: that published in the World Economic Forum Report and that in the IMD's World Competitiveness Yearbook. In particular, the methodology used by the World Economic Forum (WEF) is very closely related to Porter's diamond model. It defines 'global competitiveness' as the "set of institutions, policies, and factors that determine the level of productivity of a country" (Schwab 2015). Porter also states that international competitiveness has a set of microeconomic determinants (such as firm strategies and rivalry), macroeconomic conditions (such as demand) and factors determining government power. Thus, the methodology proposed by the WEF is based on the assumption that international competitiveness is such a multidimensional phenomenon that the most appropriate approach to assessing it as a single indicator involves a compilation of many individual competitiveness indicators. Following this assumption, the WEF constructed the Growth Competitiveness Index (GCI), which includes a weighted average of many different components, grouped into 12 pillars of competitiveness with each of them measuring a different aspect of competitiveness.

Although the GCI is one of the most accepted and recognized indicators of international competitiveness in the literature, it is not exempt from criticism. According to Berger and Bristow (2009), the lack of a good theoretical basis (especially for the selection of variables) is the most important limitation. Therefore, in the international competitiveness literature there are still open questions, especially about the relationship between historical and modern economic theories and contemporary concepts of international competitiveness.

\section{The method}

\subsection{Data collection}

A database is specifically constructed for the purposes of this study. This is an essential component of a bibliometric study because it must contain the scholarly literature represented in the discipline analysed. The three databases most used for bibliometric research are the WoS, Scopus, and Google Scholar, but consistency and accuracy greatly vary between them (Bar-Ilan 2008; Kulkarni et al. 2009). ${ }^{1}$ In this study, I follow the methodology of bibliometric database choice proposed by Yang and Meho (2007), who suggest combining information from a variety of sources

\footnotetext{
1 Web of Science covers 12,000 indexed journals from the year 1900. Scopus covers 20,000 peerreviewed journals, including those published by Elservier, Emerald, Informs, Taylors \& Francis, Springer and Interscience, but it is limited to articles published after 1995. Google Scholar is an unpublished bibliometric database offered by Google, and currently it covers metrics of articles published during the years 2009-2013 (Kumar et al. 2015).
} 
(databases) in the analysis to reduce the risk of the database not being representative or exhaustive. Yang and Meho also consider WoS the gold standard for bibliometric studies, although it is far from perfect (Yang and Meho 2007). Scopus and Google Scholar, which may assist in providing a more comprehensive picture of scholarly communication among researchers, should be treated as complementary sources.

In the first step, data for the analysis was collected from the Web of Science database on 11 March 2015. The question formulated was: "Topic: 'international competitiveness', refined by: Web of Science category: 'economics' and document types: articles, proceedings papers; timespan: all years. Indexes: sci-expanded, ssci a \& hci, cpci-s, cpci-ssh." The search covered articles in scientific journals and conference publications that contained the phrase 'international competitiveness' in the title, abstract or keywords. The findings cover publications in the years 1945-2014 made in the scientific discipline 'economics' in the Web of Science Core Collection, i.e. in the Science Citation Index Expanded [SCI-EXPANDED], the Social Sciences Citation Index [SSCI], the Conference Proceedings Citation IndexScience [CPCI-S] and the Conference Proceedings Citation Index-Social Sciences $\&$ Humanities [CPCI-SSH]. The total number of documents found was 1067. The search results were then manually verified by assessing the compliance of the results with the search criteria.

The second step was to make the same search in Scopus and Google Scholar, using the same filters for article titles, abstracts and keywords as in WoS. The results were saved in Endnote software and then analysis of affinity with the sampling from WoS was carried out. For further data processing, only the records from Google Scholar and Scopus which had a minimum of 10 citations and had not previously been found in Web of Science were selected. From the two additional databases 107 new publications related to international competitiveness were obtained. The final database consisted of 1174 records.

\subsection{The sample}

The database created (the sample) consists of 1174 publications by 1970 authors, which were published in 426 journals (Table 1). The authors are from 67 countries and represent 921 institutions. These publications have a total of 27,502 references cited, 1055 citations in the sample and 77,714 citations in WoS.

Figure 1 shows the distribution of the 1174 published economics articles over time. The first publications in the sample appeared in the 1960s, and over the next two and a half decades scientific interest in international competitiveness was small and limited to a few research papers annually. We can observe three breakthroughs

Table 1 Sample characteristics Source: HistCite calculation based on the database created

Years 1945-2014

\begin{tabular}{lll}
\hline Publications: 1174 & Authors: 1970 & Journals: 426 \\
Countries: 67 & Institutions: 921 & Number of references: 27,502 \\
Number of citations: 1055 & Citations in WoS: 77,714 & \\
\hline
\end{tabular}




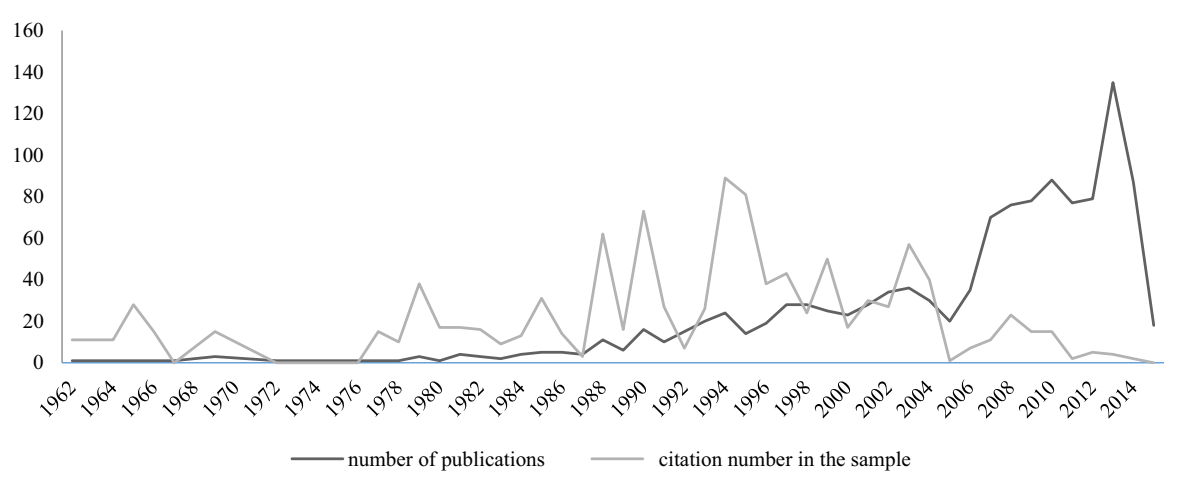

Fig. 1 Evaluation of publications in the sample (1945-2014). Source: HistCite calculation based on the database created

in the number of publications on international competitiveness: the first in 1988, when the annual number of publications reached the number published during the whole of the previous decade, and the remaining two in 1994 and 2007 with doublings of the number of annually published works. Therefore, only from 2007 can we talk about a boost in the interest in international competitiveness issues, because thereafter the number of publications related to international competitiveness ranged from 80 to 140 per year. This was mainly due to an explosion in competitiveness studies at the region and city levels and studies related to regulations, institutions and clustering processes and their impact on international competitiveness growth.

Of course, a clear upward trend in the number of publications in international competitiveness is strongly related to the overall trend of increasing numbers of papers and journals in economics observed from the 90s (the number of yearly submissions to just the top five economics journals nearly doubled between 1990 and 2012 (Card and DellaVigna 2012). This trend was fuelled by the founding of new research centres, and masters and doctoral studies on international competitiveness, and has been observed in the development of other scientific fields such as, for example, entrepreneurship research (Ferreira et al. 2015). In contrast to the increasing number of publications related to international competitiveness, the number of citations grew until 1994 and then unexpectedly diminished. One can hypothesize that the most important publications on international competitiveness were published two decades ago and that the publications from the last decade do not contribute anything new or are poorly connected to the core publications from two decades before.

The majority of the publications in the sample were published in journals with a general economic profile: the American Economic Review, the Economic Journal and the Journal of International Economics (Table 2). This is probably due to the fact that there is not a single journal in the JCR list which is exclusively dedicated to competitiveness/international competitiveness issues. 
Table 210 Sampled journals and numbers of citations Source: HistCite calculation based on the database

\begin{tabular}{lll}
\hline & Journal & Number of citations \\
\hline 1 & American Economic Review & 89 \\
2 & Economic Journal & 68 \\
3 & Journal of International Economics & 61 \\
4 & Journal of Political Economy & 50 \\
5 & Journal of Economic Literature & 38 \\
6 & Kyklos & 38 \\
7 & Weltwirtschaftliches Archiv-Review of Word Economics & 38 \\
8 & Journal of Environmental Economics and Management & 36 \\
9 & Journal of Economic Perspectives & 35 \\
10 & Foreign Affairs & 33 \\
\hline
\end{tabular}

\subsection{Analysis procedure}

Bibliometrics has been briefly characterized as 'a science of science' (de Solla Price 1963) or 'research on research' (Pincus et al. 1993), but most often as 'the application of mathematical and statistical methods to books and other media of communication' (Pritchard 1969). Bibliometric analysis is based on three bibliometric laws-Lotka's law, Bradford's law and Zipf's law ${ }^{2}$ - and on two assumptions: that the goal of researchers is to disseminate the results of their research and studies through a variety of communication media, including writing, which lies at the core of the academic tradition; and that scholars have to publish in order to build a reputation and advance their careers (Archambault and Gagné 2004). The aim of bibliometric studies is to search for regularities in the structure of the literature, i.e. to make order out of documentary chaos and to understand the patterns in the literature (De Bellis 2009). Bibliometric analysis is a research field that analyses publications, citations and their sources of information (Merigó et al. 2015a). Often, bibliometric studies are used to obtain overviews of a research field through analysis of the leading researchers (Bonilla and Merigó 2015) or of one journal to provide a broad picture of the leading trends in that journal (Merigó et al. 2015b).

According to Archambault and Gagné (2004), three main groups of methods are principally used in bibliometrics. The first involves counting numbers of publications in journals during a specific time frame, which can be treated as indicators of the output of a set or subset within the scientific system (Price 1951). This may be used for the evaluation and comparison of the research performance of individual researchers, departments and research institutions (Garfield et al. 1978; Adam 2002; Bornmann et al. 2008). Second, citation analysis is a search for the value or impact

\footnotetext{
${ }^{2}$ Lotka's law refers to the frequency of publication by authors in a given field, where the number of authors making $n$ contributions is about $1 / \mathrm{n}^{\mathrm{a}}$ of those making one contribution, where $a$ nearly always equals two (Lotka 1926). Bradford proposed the concepts of core and scatter. Core refers to the small number of journals that publish the most papers in a field; scatter refers to the spread of the literature over many publications (Bradford 1985). Zipf's law refers to the distribution of keywords, with a word's frequency being inversely proportional to its ranking in a frequency table (Zipf 1949).
} 
of a paper, a journal or a research group (Garfield 1955; Lundberg 2006; Garfield 2007; Koskinen et al. 2008). Citation analysis focuses on an examination of the frequency, patterns, and graphic representations of citations (citation networks), on assessing information resources and evaluating scholarly contributions, and on mapping research fields to study their intellectual structures. It is also used to track knowledge flows and the diffusion of ideas (Garfield 1979; Small 1999; Zhao and Strotmann 2015). Third, co-citation analysis, co-word analysis and bibliographic coupling are used to study the development of emerging fields in a scientific discipline and to determine linkages among them (Teixeira and Sequeira 2009).

The bibliometric methods and indicators used in this paper can be divided into four groups. First, I provide a descriptive analysis of the basic bibliometric indicators (number of citations) to indicate the most-cited publications and authors in the international competitiveness economics literature.

Second, I use a bibliometric method called citation network analysis, based on cited references, to discover the relationship between the most-cited publications (Small 1973). In citation network analysis, a set of objects (documents, authors, journals, or groups of them) is selected to represent a research area (Emrouznejad and Marra 2014). The strengths of the interrelationships (or levels of connectedness) between these objects are measured with various scores derived from citation counts (Zhao and Strotmann 2015). In this paper, the database created is processed using HistCite software to analyse and visualize direct citations to generate a network of the most-cited works. HistCite uses bibliographic records (including cited references) as an input and offers as outputs various tables and graphs with bibliometric data about the knowledge domain under study (Garfield et al. 2006). It allows a citation-based historiograph to be drawn showing how the timeline of publications in a collection narrows, indicating the citation links (Garfield et al. 2003). In a historiograph, the vertical axis represents time and the horizontal axis shows citation network nodes. Each node (a circle in the diagram) refers to a single publication with a unique number in the database, and the size of the node reflects the number of citations in the sample. Arrows show the relationship between the cited publications, i.e. from the publication analysed to previous publications. To create the historiograph, the forty publications with the largest number of citations in the sample are selected. This number of publications is considered to be optimal as it allows the evolution of research to be shown and at the same time allows relatively good readability of the figure (Griffith et al. 1974). HistCite's algorithmic historiographs illustrate the publications associated with the development of a field by indicating the most-cited papers in the sample. If the development of a science can be described as a series of chronological events (Garfield et al. 1964), and the citation network is acknowledged as an emergent property of scientists' activities (Fujigaki 1998), one can consider that the network formed by relations between the most frequently cited documents represents the intellectual base from which further developments in the field unfold (Lucio-Arias 2010).

Third, using the historiographical approach presented above, I am able to show where an international competitiveness issue began, and identify both the bibliographic antecedents and descendants of its principal papers or authors. However, a citation network based on numbers of citations accumulated over time 
shows many paths connecting the oldest and newest most-cited publications, but which of the paths are the most important? Additionally, if we include more than 40 cited documents, the number of possible paths greatly increases and the readability of the historiograph sharply decreases. Therefore, I use a method called main path analysis to extract the main routes of the networks and to trace the main academic trajectory of an international competitiveness field, i.e. to highlight the structural backbone in the development of the scientific field (Nooy et al. 2005; Lucio-Arias and Leydesdorff 2008). Main path analysis calculates the connectivity of the links in terms of their degree of centrality and outlines the path formed by the nodes of the highest degree (Lucio-Arias 2010). The main path is constructed by selecting the connected documents with the highest scores, which are calculated by taking into account numbers of citations and numbers of cited references, until an end document is reached (Batagelj 2003). Hummon and Doreian (1989) propose a methodology to compute the weights of each arc in a network and to identify the most important part of a citation network. They offer three measures of node importance: the node pair projection count, which accounts for the number of times each link is involved in connecting all node pairs, the search path link count, which accounts for the number of all the possible search paths through the network emanating from an origin; and the search path node pair, which accounts for all the connected vertex pairs along the paths (Hummon and Doreian 1989). The methodology proposed by Hummon and Doreian was extended by Verspagen (2007), whose approach concentrates not on identification of a single main path but on finding multiple sequences of citation links.

In this paper, I choose key-route main path analysis, which is an extended version of Hummon and Doreian's method, proposed by Verspagen (2007), which adds an algorithm to search for multiples paths and guarantees the inclusion of the most significant links in these multiple paths (Liu and Lu 2012). To identify the key-route main paths, I use a freely available program called Pajek, constructed by Batagelj (Batagelj 2001). The procedure of key-route main path analysis consists of three steps (Hung et al. 2014). First, the citation network of the 40 most-cited papers is analysed to identify two types of nodes: 'source' nodes, which are cited but cite no other nodes, and 'sink' nodes, which cite other nodes but are not cited. The relevant paths will begin at sources and always end at sinks. Second, links with the largest SPC (key-routes) value are selected, where SPC is the number of times the link is traversed if one exhausts the search from all the sources to all the sinks in a citation network. Third, the end node of each key route becomes the starting point from which to search for the links with the largest SPC. The process is continued until each key route hits a sink. Simultaneously, a search backward from the start node of the key route(s) is made until a source is hit. This procedure based on forward and backward searches guarantees that the desired links (with the largest SPC value) are included in the main paths. Main path analysis is a method that has some limitations. We can only identify the 'most obvious routes' and can lose substantial amounts of information because certain key publications not listed in the most obvious route may be ignored (Tu and Hsu 2015).

Fourth, in addition to identifying the most important publications and the main paths of the scientific development of international competitiveness concepts, I also 
aim to identify the key research domains in international competitiveness studies. For this purpose, I employ term co-occurrence analysis. This bibliometric method is normally used to ascertain trends (Yale and Gilly 1988; Cho and Khang 2006; Williams and Plouffe 2007) and to identify research 'hotspots'/sub-domains (Helgeson et al. 1984). By applying the term co-occurrence technique, we analyse the distance between two terms, where a term is understood as a sequence of nouns in text documents. The more often two terms co-occur in the same line of text, the smaller the distance between them. Terms in the sample records corresponding to publications on international competitiveness are extracted, with the record's fields, title, abstract and keywords being used as term sources. The term extraction, performed by means of the VOSviewer program, is done using a natural language processing algorithm (NLP) (Van Eck and Waltman 2011). A three-step term identification process (Van Eck 2011) is followed. First, a linguistic filter is applied to the corpus in order to identify noun phrases. The filter selects all the word sequences that consist exclusively of nouns and adjectives and that end with a noun, and converts plural noun phrases into singular ones. In the second step, the 'unithood' of the noun phrases (only for phrases of two or more words) is calculated in order to identify semantic units and to eliminate noun phrases that start with uninteresting adjectives, such as first, many, new, and some (Van Eck and Waltman 2010). To measure unithood, the 'likelihood' ratio is calculated, where the number of occurrences of the phrase, the number of occurrences of the phrase without the first word, and the number of occurrences of the first word of the phrase are compared. VOS software only chooses semantic units for further analysis if the natural logarithm of their likelihood ratio is less than -30 . In the third and final step, the 'termhood' $\left(\boldsymbol{u}_{\boldsymbol{k}}\right)$ of semantic units is measured, i.e. VOS calculates the degree to which the occurrences of a semantic unit are biased towards one or more topics:

$$
\left(\boldsymbol{u}_{\boldsymbol{k}}\right)=\sum_{j=1}^{\boldsymbol{J}} \boldsymbol{p}_{\boldsymbol{j} \log \boldsymbol{p}_{j}}
$$

where $\boldsymbol{p}_{\boldsymbol{j}}=\frac{\boldsymbol{P}\left(\boldsymbol{t}_{j} / \boldsymbol{u}_{\boldsymbol{k}}\right) / \boldsymbol{P}\left(\boldsymbol{t}_{j}\right)}{\sum_{j^{\prime}=1}^{J} \boldsymbol{P}\left(\boldsymbol{t}_{\boldsymbol{j}^{\prime}} / \boldsymbol{u}_{\boldsymbol{k}}\right) / \boldsymbol{P}\left(\boldsymbol{t}_{\boldsymbol{j}}^{\prime}\right)}$ and $\log 0$ is defined as 0 .

Next, the terms identified are placed on a map in such a way that the distance between any two items reflects the similarity between them. The degree of similarity is calculated using the association strength (Eq. 2) and the terms are located on the map by minimization of the weighted sum of the squared distances between the items (Eqs. 3, 4) (Van Eck and Waltman 2007; Van Eck et al. 2006):

$$
A s_{i j}=\frac{C_{i j}}{c_{i} c_{j}},
$$

where $c_{i j}$ is the number of co-occurrences of items $\mathrm{i}$ and $\mathrm{j}, \boldsymbol{c}_{\boldsymbol{i}}$ is the total number of co-occurrences of item $i$, and $c_{j}$ the total number of co-occurrences of item $j$.

$$
\boldsymbol{V}\left(\boldsymbol{X}_{1} \ldots \boldsymbol{X}_{N}\right)=\sum_{i<j} \boldsymbol{S}_{i j}\left\|\boldsymbol{X}_{i}-\boldsymbol{X}_{j}\right\|^{2}
$$




$$
\frac{2}{n(n-1)} \sum_{i<j}\left\|X_{i}-X_{j}\right\|=1,
$$

where $\mathrm{n}$ denotes the number of nodes in the network, $\boldsymbol{X}_{\boldsymbol{i}}$ denotes the location of node $i$ in a two-dimensional space, and $\left\|\mathbf{X}_{\mathbf{i}}-\mathbf{X}_{\mathbf{j}}\right\|$ denotes the Euclidean distance between nodes $i$ and $j$.

The terms identified can be grouped into clusters according to their similarity, and every cluster may be seen as one topic (Van Eck et al. 2010). To cluster the terms, VOSviewer maximizes the following function:

$$
V\left(c_{1 \ldots} c_{n}\right)=\sum_{i<j} \delta\left(c_{i}, c_{j}\right)\left(s_{i j}-\gamma\right)
$$

where $\boldsymbol{c}_{\boldsymbol{i}}$ denotes the cluster to which node $\mathrm{i}$ is assigned, $\boldsymbol{\delta}\left(\boldsymbol{c}_{\boldsymbol{i}} \boldsymbol{c}_{\boldsymbol{j}}\right)$ denotes a function that equals 1 if $\boldsymbol{c}_{\boldsymbol{i}}=\boldsymbol{c}_{\boldsymbol{j}}$ and 0 otherwise, and $\boldsymbol{\gamma}$ denotes a resolution parameter that determines the level of detail of the clustering (the higher $\gamma$ is, the higher the number of clusters). Clustering terms allows the following questions to be answered. How do these topics or these fields relate to each other? How has a certain scientific domain developed over time

\section{Results}

\subsection{Citation analysis}

The analysis begins with identification of the most important publications based on their numbers of citations in the sample (Table 3). The most significant publication in the evolution of research on international competitiveness in economics was Fragerberg's 'International competitiveness', which, using data for 15 OECD countries for the period 1961-1983, shows that in the medium and long run factors related to technology and production capacity are more important for economic growth than price or the cost competitiveness of the economy (Fagerberg 1988). The second most important publication is Krugman's paper 'Competitiveness - a dangerous obsession', on the unproductive discussion around international competitiveness, particularly at the macro level. This publication started a heated debate in the scientific community between the opponents and supporters of Krugman, who still today calls discourse about international competitiveness "discussion on the theory of foreign trade, dressed in a new rhetoric" (Fujita and Krugman 2003). It is hard not to agree with Krugman's thesis when analysing the remaining eighteen most-cited publications on international competitiveness in the sample. They mainly analyse the determinants of competitive advantages and patterns in international trade growth, such as trade liberalization (Balassa 1965), intra-industry effects (Melitz 2003), economies of scale, product differentiation (Dixit and Stiglitz 1977; Krugman 1979a, b, 1980), regulations and environmental policy (Tobey 1990; Jaffe et al. 1993; Barrett 1994; Porter and Van der Linde 1995) and innovations (Greenhalgh 1990). The Krugman thesis, that international 
Table 320 main papers related to international competitiveness in economics Source: HistCite calculation based on the database created

\begin{tabular}{|c|c|c|c|c|}
\hline$\# \mathrm{Rc}$ & Author & Title of publication/year & CS & CWoS \\
\hline 51 & Fagerberg J. & International competitiveness/1988 & 39 & 147 \\
\hline 131 & Krugman P.R. & Competitiveness_-a dangerous obsession/1994 & 33 & 292 \\
\hline 154 & $\begin{array}{l}\text { Jaffe A., Peterson S., } \\
\text { Portney P., Stavins R. }\end{array}$ & $\begin{array}{l}\text { Environmental regulations and the competitiveness of } \\
\text { United States manufacturing-what does the evidence } \\
\text { tell us/1995 }\end{array}$ & 29 & 554 \\
\hline 3 & Balassa B. & $\begin{array}{l}\text { Trade liberalization and revealed comparative } \\
\text { advantage/1965 }\end{array}$ & 28 & 394 \\
\hline 65 & Tobley J. & $\begin{array}{l}\text { The effects of domestic environmental policies on } \\
\text { patterns of world trade-an empirical test/1990 }\end{array}$ & 25 & 172 \\
\hline 159 & $\begin{array}{l}\text { Porter M.E., } \\
\text { Vanderlinde C. }\end{array}$ & $\begin{array}{l}\text { Toward a new conception of the environment- } \\
\text { competitiveness relations/1995 }\end{array}$ & 23 & 1175 \\
\hline 33 & $\begin{array}{l}\text { Bander J.A., Spencer } \\
\text { B.J. }\end{array}$ & $\begin{array}{l}\text { Export subsidies and international market share rivalry/ } \\
1985\end{array}$ & 20 & 624 \\
\hline 140 & Barrett S. & $\begin{array}{l}\text { Strategic environmental policy and international trade/ } \\
1994\end{array}$ & 18 & 185 \\
\hline 17 & Krugman P.R. & $\begin{array}{l}\text { Scale economies, product differentiation and the pattern } \\
\text { of trade/1980 }\end{array}$ & 17 & 936 \\
\hline 379 & Melitz M. & $\begin{array}{l}\text { The impact of trade on intra-industry reallocations and } \\
\text { aggregate industry productivity/2003 }\end{array}$ & 17 & 1590 \\
\hline 4 & Vernon R. & $\begin{array}{l}\text { International investment and international trade in } \\
\text { product cycles/1966 }\end{array}$ & 15 & 865 \\
\hline 6 & Armington P.S. & $\begin{array}{l}\text { Theory of demand for products distinguished by place } \\
\text { of production/1969 }\end{array}$ & 15 & 865 \\
\hline 12 & Dixit A.K., Stiglitz J.M. & $\begin{array}{l}\text { Monopolistic competition and optimum product } \\
\text { diversity/1977 }\end{array}$ & 15 & 2095 \\
\hline 15 & Krugman P.R. & $\begin{array}{l}\text { Increasing returns, monopolistic competition and } \\
\text { international trade/1979 }\end{array}$ & 15 & 703 \\
\hline 53 & Lucas R.E. & On the mechanics of economic development/1988 & 15 & 3763 \\
\hline 39 & Romer P.M. & Increasing returns and long-run growth/1986 & 14 & 3647 \\
\hline 63 & Greenhalgh C. & $\begin{array}{l}\text { Innovations and trade performance in the United- } \\
\text { Kingdom } / 1990\end{array}$ & 14 & 44 \\
\hline 151 & Amable B. Verspagen B. & The role of technology in market share dynamics/1995 & 14 & 44 \\
\hline 21 & Soete L.L.G. & $\begin{array}{l}\text { A general test of the technological gap trade theory/ } \\
1981\end{array}$ & 13 & 63 \\
\hline 211 & Krugman P.R. & Making sense of the competitiveness debate/1996 & 12 & 96 \\
\hline
\end{tabular}

$C S$ number of citations in the sample, $C W o S$ number of citations in web of science

competitiveness discourse is quite heavily focused on international trade, can therefore be confirmed. Moreover, according to Krugman, defining and studying international competitiveness using international trade indicators is an appropriate approach for analysis of the subject (Krugman 2011).

To find the most influential scientists, those whose contribution to the study of international competitiveness in economics is the largest, a ranking of authors based on their numbers of citations in the sample is created (Table 4). The results are 
Table 4 Ranking of authors with the highest number of citations in the sample Source: Author's own calculation based on the database created

\begin{tabular}{llllr}
\hline Ranking & Authors & Number of citations in the sample & Number of publications [Q] & CS/Q \\
\hline 1 & Krugman P. & 96 & 7 & 13.7 \\
2 & Fagerberg J. & 52 & 4 & 13.0 \\
3 & Balassa B. & 39 & 2 & 19.5 \\
4 & Brander J. & 29 & 2 & 14.5 \\
5 & Jaffe A. & 29 & 1 & 29.0 \\
5 & Peterson S. & 29 & 2 & 14.5 \\
6 & Portney P. & 29 & 1 & 29.0 \\
7 & Spencer B. & 29 & 2 & 14.5 \\
8 & Stavins R. & 29 & 1 & 29.0 \\
9 & Anderson J.E. & 25 & 2 & 12.5 \\
10 & Porter M.E. & 24 & 3 & 8.0 \\
\hline
\end{tabular}

strongly correlated with the ranking of most-cited publications. The most frequently cited author is Krugman, whose permanent criticism of research on international competitiveness, particularly at the macro level, was a strong impetus for further studies in this area. The second most-cited economist dealing with the analysis of international competitiveness is Fragerberg, with four publications in the sample and fifty citations in it. Third place in the ranking belongs to Balassa, whose two publications, however, have already been cited 2.5 times less than Krugman's publications.

\subsection{Citation network analysis}

A second important part of this analysis is not only identification of the most-cited publications and authors, but also to establish networks between them. The best tool for visualization of these relationships is a historiograph (Fig. 2). A historiograph is a time-based network diagram of the papers in a bibliography and their citation relationships to each other. I have attempted to trace the evolution of international competitiveness research in economics. HistCite enables one to draw a citation network among highly cited papers, and from this one gets a feel for the evolution of the subject (or research front) over the years. What HistCite does is to reduce the clutter: in the huge population of papers and citations that constitute the sample, one would not get anywhere if one tried to view all the citation links. By clever use of algorithms and networking tools, HistCite prunes many of the not so important links and leaves one with a manageable and compact scientograph.

Analysis by historiograph does not allow full confirmation of the hypothesis that the roots of international competitiveness theory come from classical theories of international trade. Although the oldest among the forty most-cited publications in the sample relate to the works of Balassa (Nos. 2 and 3) and Vernon (No. 4), they are only slightly connected by a network of citations with other publications, so 


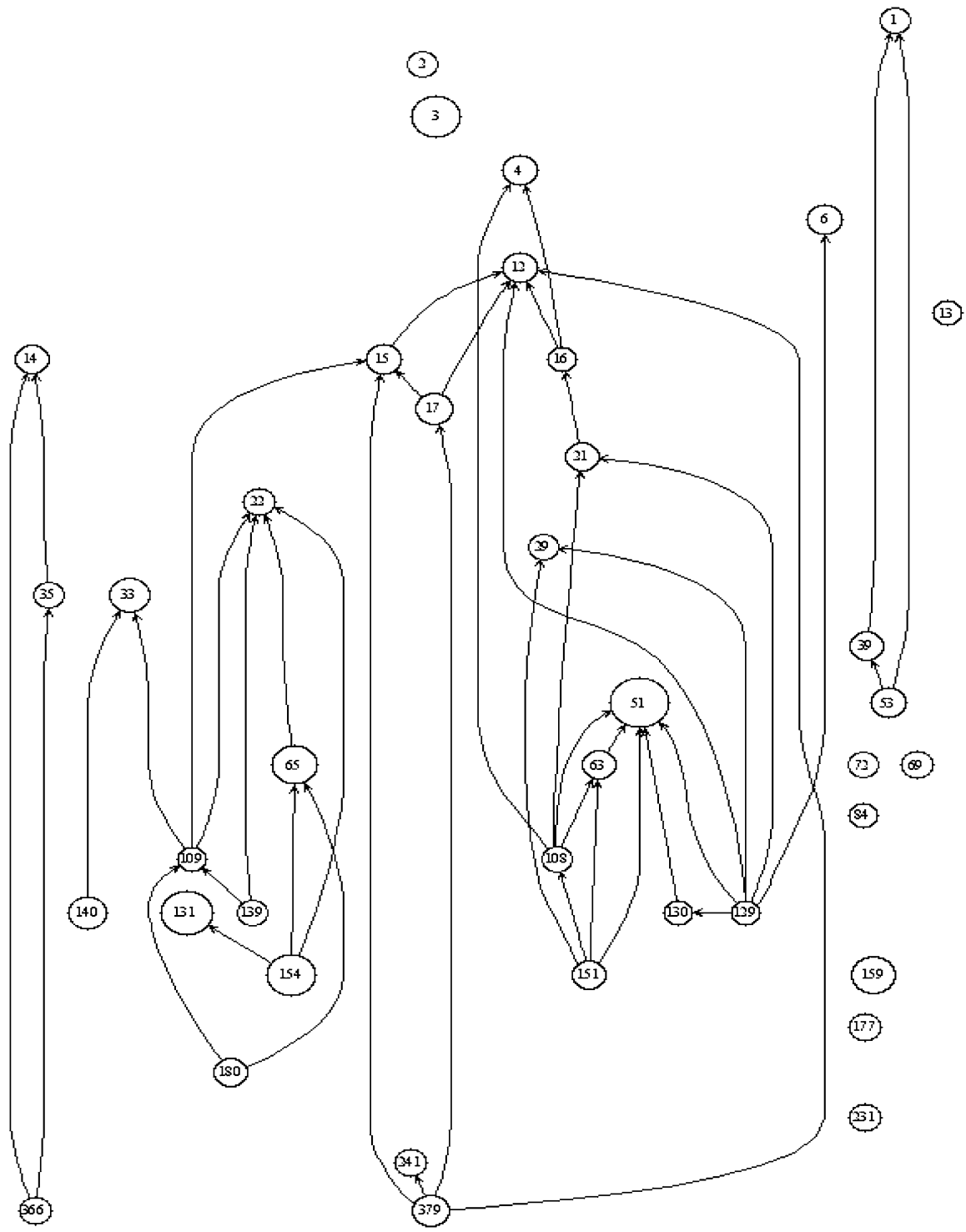

Fig. 2 Historiograph of the 40 most highly-cited publications in the sample. Source: Author's own calculation based on the database created

their role in the evolution of international competitiveness theory is negligible (Balassa 1964, 1965; Vernon 1966). The status of pioneering works should be attributed to publications from the end of the 1970s, i.e. works by Dixit and Stiglitz (No. 12), Krugman (Nos.15, 16, and 17) and Anderson (No. 14) (Dixit and Stiglitz 1977; Krugman 1979a, b, 1980; Anderson 1979). 
The most important period in the development of international competitiveness research is 1985-1995. The vertical shape of the historiograph suggests that the most ground-breaking publications were published exactly in this period and they still provide the most important theoretical basis for competitiveness studies. These are works by Fragerberg (No. 51), Krugman (No. 131), Jaffe (No. 154), Tobey (No. 65), Brander (No. 33) and Porter (No. 133) (Brander 1985; Fagerberg 1988; Tobey 1990; Krugman 1994; Porter and Van der Linde 1995). The great majority of later publications contain references to these articles.

No paper published after 2005 is included in the top 40 most-cited publications in the database created. The most recent publications in this ranking are written by Melitz, and Copeland and Taylor (Melitz 2003; Copeland and Taylor 2004). Both publications refer to new research trends in foreign trade analysis: Melitz's model explains the relationship between productivity and export activity (Gkypali et al. 2015), and Copeland and Taylor analyse the impact of national environmental regulations on international trade.

The absence of papers published after 2003 and the presence of only two papers among the 40 most-cited records in the sample indicate that new publications have not proved to be significant, or maybe that they concentrate on different international competitiveness issues that are only slightly connected with the previously-identified core publications. I decide to look closely at the papers published during the last 12 years. Of the 856 publications in the years 2003-2015 relating to international competitiveness issues, only 60 of them have a citation in the sample. On average, each of these publications is cited in the sample only 1.5 times and almost always among papers published after 2003. The most influential (most-cited) publications focus on the impact of technology (Freeman 2004; Montobbio 2003; Montobbio and Rampa 2005; Fagerberg et al. 2007), environment (Neary 2006; Demailly and Quirion 2008; Greaker 2003), on international competitiveness growth and on regional (Simmie 2003; Boschma and Iammarino 2009) and urban aspects of competitiveness (Rutkauskas 2008). Unfortunately, a historiograph based on the relationships between papers published between 2003 and 2015 indicates only very slight connections among them, exactly as they have only slight connections with the publications from 1969 to 2003. This analysis shows that when the development of international competitiveness research after 2003 is taken into account, the idea that there is a commonly accepted theory of international competitiveness becomes more and more unreal.

\subsection{Key-routes main path analysis}

In the next step of the study, I analyse more precisely the paths in the historiograph created (Fig. 2). Many paths connecting the oldest and newest most-cited publications can be identified, but the aim is to find the most important ones. I apply key-route main path analysis to find the core paths, i.e. to visualize the key knowledge diffusion paths in international competitiveness. Based on the assumption that the main international competitiveness topics are embedded in the governing structure of the knowledge diffusion paths, once the governing structure is made to surface through the key-route approach, the stories of international 
competitiveness speak for themselves. The historiograph in Fig. 2 is created based on the number of citations in the sample of documents, which accumulate over time. This can be expected to be to the disadvantage of relatively recent papers. Main path analysis considers both the citations which a document receives and the documents it cites. A publication that links many publications and has many publications linking to it will probably be part of a main path.

I use Pajek software to determine the SPC values for each citation link and then to search for the key-route paths. Among the 40 most often-cited publications in the sample (connected by 120 links), eighteen of them form the backbone of the international competitiveness network. They create five main paths and the start, intermediate and final publications of each path are presented in Table 5.

For all the paths, the Dixit and Stiglitz publication 'Monopolistic competition and optimum product diversity' plays the role of root. It underlines the role and character of competition in many markets, i.e. it is almost always imperfect, the products on the market are highly differentiated and firms have to face downward-sloping demand curves. This means that models which assume perfect competition provide an inadequate description of how markets work. The fact that the core paths start from Dixit and Stiglitz's publication allows confirmation of the thesis that the international competiveness concept comes from models of competition. The second step in the knowledge diffusion of international competiveness issues (common to almost all the paths) is Krugman's (1979b) article 'Increasing Returns, Monopolistic Competition and International Trade.' This focuses on the source of gains in international trade, where firms compete with each other in an imperfect competitive market and increasing returns to scale decide trade advantages. The presence of Krugman's publication in the main paths indicates that the international competitiveness concept is neatly connected to and often measured via international trade performance (in all the key routes).

Table 5 Five main paths in international competitiveness Source: Author's own calculation in Pajek software

\begin{tabular}{|c|c|c|c|c|c|}
\hline $\begin{array}{l}\text { Key } \\
\text { route }\end{array}$ & Step 1 & Step 2 & Step 3 & Step 4 & Step 5 \\
\hline No 1 & $\begin{array}{l}\text { Dixit and } \\
\text { Stiglitz } \\
(1977)\end{array}$ & Krugman (1979a) & Soete (1981) & Amendola et al. (1993) & $\begin{array}{l}\text { Amable and } \\
\text { Verspagen } \\
(1995)\end{array}$ \\
\hline No 2 & $\begin{array}{l}\text { Dixit and } \\
\text { Stiglitz } \\
(1977)\end{array}$ & Krugman (1979b) & $\begin{array}{c}\text { Krugman } \\
(1980)\end{array}$ & Bergstrand (1989) & $\begin{array}{l}\text { Anderson and } \\
\text { Wincoop } \\
(2003)\end{array}$ \\
\hline No 3 & $\begin{array}{l}\text { Dixit and } \\
\text { Stiglitz } \\
(1977)\end{array}$ & Krugman (1979b) & $\begin{array}{l}\text { Markusen and } \\
\text { Rutherford } \\
\text { (1993) }\end{array}$ & $\begin{array}{l}\text { Kennedy (1994) or Van } \\
\text { Beers and Van den Bergh } \\
\text { (1997) }\end{array}$ & $\begin{array}{l}\text { Copeland and } \\
\text { Taylor } \\
(2004)\end{array}$ \\
\hline No 4 & $\begin{array}{l}\text { Dixit and } \\
\text { Stiglitz } \\
(1977)\end{array}$ & Krugman (1979b) & $\begin{array}{c}\text { Krugman } \\
(1980)\end{array}$ & Krugman (1991) & $\begin{array}{l}\text { Audretsch and } \\
\text { Feldman } \\
\text { (1996) }\end{array}$ \\
\hline No 5 & $\begin{array}{l}\text { Dixit and } \\
\text { Stiglitz } \\
(1977)\end{array}$ & $\begin{array}{l}\text { Krugman }(1979 b) \\
\text { or Krugman } \\
(1980)\end{array}$ & Melitz (2003) & $x$ & $\times$ \\
\hline
\end{tabular}


Starting from the beginning of the 1990s, the paths in international competitiveness diverge. Path no. 1 connects international competitiveness (understood as export performance) with technology. Publications such as 'A Model of Innovation, Technology Transfer, and the World Distribution of Income' by Krugman (1979a), 'A general test of technological gap trade theory' by Soete (1981), 'The Dynamic of International Competitiveness' by Amendola et al. (1993), and 'The role of technology in market shares dynamics' by Amable and Verspagen (1995) indicate that technological capacities (patents, investments in technology) are a major determinant in shaping the dynamics of exports.

Path no. 2 represents knowledge diffusion in international competitiveness based on the above-mentioned publications by Dixit and Stiglitz (1977) and Krugman (1979b) and also by Krugman's article 'Scale Economies, Product Differentiation, and the Pattern of Trade', Bergstrand's (1989) 'The Generalized Gravity Equation, Monopolistic Competition, and the Factor-Proportions Theory in International Trade' and Anderson and Wincoop's (2003) 'Gravity with gravitas: A solution to the border puzzle.' All these develop econometric models (gravity models) grounded in theories of differentiated goods and measure the gains from trade liberalization and the magnitude of border barriers to trade. Thus, path no. 2 connects studies of international competitiveness measured in terms of international trade performance with liberalization issues.

Path no 3 includes publications which focus on the impact of domestic environmental regulations on the international trade flow. 'Equilibrium Pollution Taxes in Open Economies with Imperfect Competition' by Kennedy (1994), 'An empirical multi-country analysis of the impact of environmental regulations on foreign trade flows' by Van Beers and Van den Bergh (1997) and 'Growth and the Environment' by Copeland and Taylor (2004) underline that relatively strict environmental policies can have a negative impact on foreign trade dynamics.

Path no 4 consists of publications related to the determinants of production location and its impact on international competitiveness. In 'Scale Economies, Product Differentiation, and the Pattern of Trade', Krugman (1980) underlines the role of large domestic markets in encouraging exports, and eleven years later in 'Increasing Returns and Economic Geography', analysing manufacturing firms, he confirms that to realize scale economies and minimize transport costs, firms tend to locate in regions with greater demand, but the location of demand itself depends on the distribution of manufacturing (Krugman 1991). The last publication in this path, ' $R \& D$ spillovers and the geography of innovation and production' by Audretsch and Feldman (1996), examines the concentration of economic phenomena such as innovation activity and new knowledge spillovers, and their strong positive impact on production concentration.

Path no. 5 is the shortest one, and it connects two economic categories: productivity and international trade growth. In 1980, Krugman's publication 'Scale Economies, Product Differentiation, and the Pattern of Trade' presented a trade model which incorporates as independent variable firm-level productivity differences. Melitz (2003) extended this model in 'Scale Economies, Product Differentiation, and the Pattern of Trade: The impact of trade on intra-industry reallocations and aggregate industry productivity.' His dynamic industry model 
with heterogeneous firms where opening to trade leads to reallocations of resources within an industry underlines above all the role of productivity in boosting firm export activity.

The key routes analysis reveals several important things: the concept of international competitiveness comes directly from competition models and is mostly defined and measured by international trade/export performance. Although the most-cited publications related to international competitiveness are by Krugman, Fragerberg and Balassa, only Krugman's works are significant in the knowledge diffusion paths of international competitiveness. These main paths show that the development of the scientific international competitiveness literature concentrates on five main economic categories: technology, liberalization, environmental regulations, location and productivity. Because the main paths analysis has been performed for only the 40 most often-cited documents in the 'international competitiveness' set, some significant research topics related to international competitiveness may be omitted. To verify this, I use a quite different method: word co-occurrence analysis, which is based not only on the most-cited documents but on all the publications in the sample.

\subsection{Term co-occurrence analysis}

In co-occurrence analysis, we assume that in each document there are sections, such as the title, abstract or keywords, that contain important terms. This co-occurrence method is a fruitful approach to examining a collection of documents through analysis of their co-occurring terms - that is, the words or phrases that appear together in designated spans of text in the same document. As a result of the analysis we obtain co-occurrence maps, which help to identify the various areas of research and understand the direction in which research is heading in the area analysed.

In my analysis, the titles, abstracts and keywords from 1174 publications are used as term sources and 18,823 unique terms are extracted from the sample. A minimum number of occurrences of 12 is set and 444 terms meet the threshold. Among the 444 terms, relevance scores are calculated by VOSviewer and then the $60 \%$ most relevant terms are selected. Finally, 266 terms are obtained, from which terms not germane to the goals of the analysis are excluded, such as specific place names, general statistical terms and units of measurement of such things as time, quantity and rate.

Figure 3 shows the term co-occurrence map, where each term is represented by a circle, and the diameter of the circle and the size of its label represent the frequency of the term, its proximity to another term indicates the degree of relatedness of the two terms. Analysis of Fig. 3 indicates that trade (the largest circle) is the most frequently mentioned word, followed by the phrases 'international trade', 'export', 'cost price', 'knowledge' and 'FDI'.

There are clearly four clusters in the figure. The first cluster can be dubbed the 'trade cluster'. This cluster groups together terms associated with trade: trade flow and international trade. We can distinguish two key topics in international competitiveness studies understood as the analysis of international trade. These are 


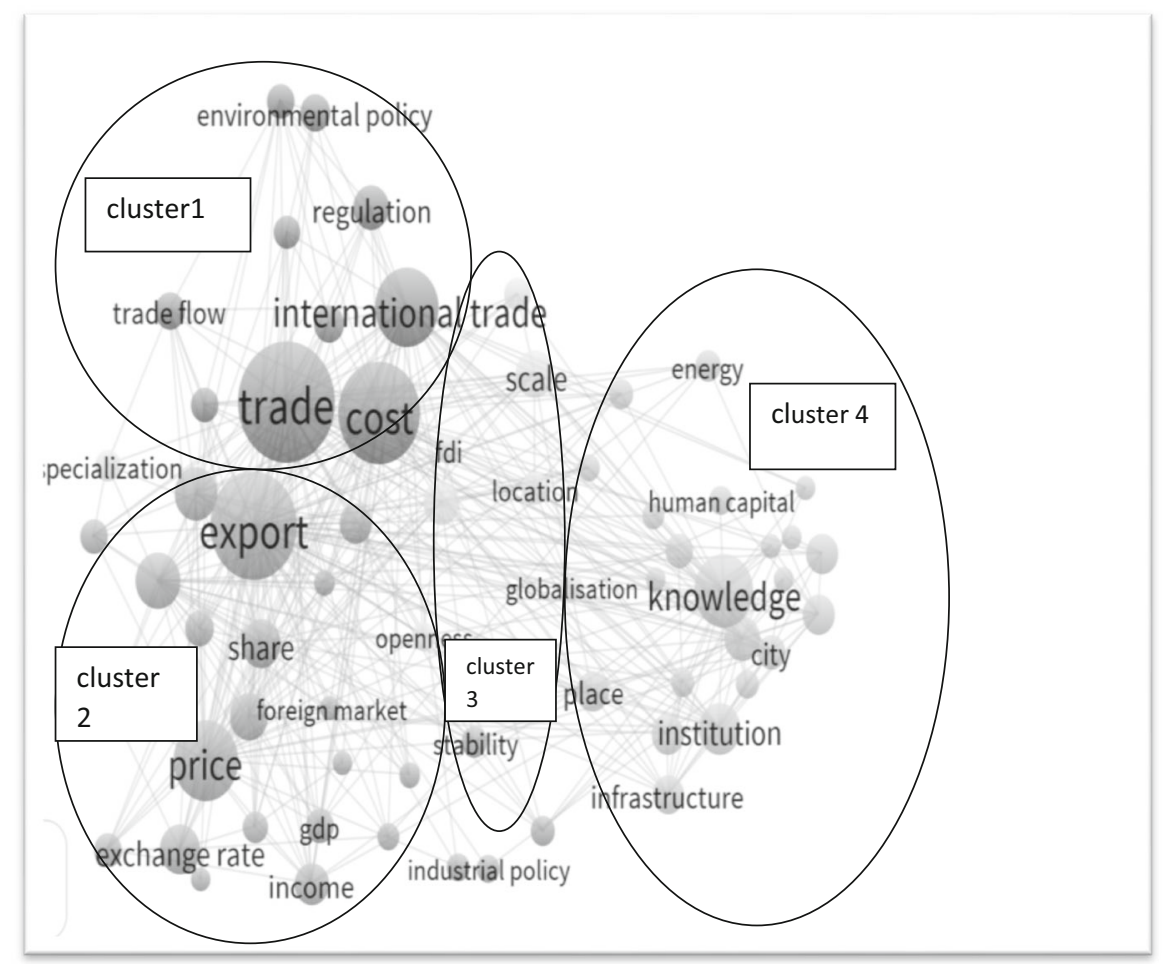

Fig. 3 Four clusters in the international competitiveness literature (1960-2014) by term co-occurrence analysis. The three most important terms in the clusters identified are: cluster 1 trade, cost, international trade; cluster 2 export, price, exchange rate, cluster 3 FDI, scale, location, cluster 4 knowledge, institution, infrastructure. Source: Author's own elaboration using VOSviewer software

the influence of regulations and environmental policy on trade and the impact of cost changes on the trade flow.

The second cluster can be called the 'export cluster' and it is connected with the narrow approach to the definition of international competitiveness, i.e. through export performance (via the export share or via the position in foreign markets). This understanding of international competitiveness refers to classical and neoclassical theories of foreign trade which emphasize the importance of the price and non-price determinants of export growth, such as exchange rates and differences in income or in GDP level between trading economies. The trade and export clusters are very close to each other and from the theoretical point of view they relate to analyses of international competitiveness in the light of foreign trade theories.

The third cluster, named the 'location cluster', points to the importance of location, broadly defined as economic distance, in the growth of international competitiveness. In this research area the impact of FDI, openness of the economy and economies of scale in the position of economies, industries and enterprises in the world market are mainly analysed. 
The last cluster, called 'knowledge \& institutions', represents research domains which are the furthest from the mainstream of the analyses represented by the first two clusters. The first of these domains is related to the role of education, knowledge and human capital in increasing international competitiveness. In the second one, the impact of the quality of institutions and the business environment are analysed. The third research area groups together terms associated with the regional aspect of international competitiveness, with a particular emphasis on city competitiveness.

To confirm the thesis that international competitiveness research domains have much changed in the last decade, I conduct term co-occurrence analysis once more, but this time only based on documents published between 2003 and 2014 (Fig. 4).

Analysis of Fig. 4 shows quite large changes in the terms co-occurring in the literature from the last 13 years analysed. We can speak about a polarization of research domains in the international competitiveness literature. Two dominant clusters can be distinguished which together group the majority of key topics. The first cluster, which is still the most important one, can be dubbed 'traditional', because it groups the most frequently occurring terms associated with exports and international trade flows. Here, we have key topics such as cost, price, exchange rate, income and FDI, which are the determinants of international trade flows in the light of old and new foreign trade theories.

The second big cluster, named 'knowledge, institution and environment', represents research domains which have become the mainstream in international competitiveness analyses in the last decade. The most recent publications on international competitiveness are related to the role of education, knowledge, human capital or $\mathrm{R} \& \mathrm{D}$ investments in increasing international competitiveness, or the

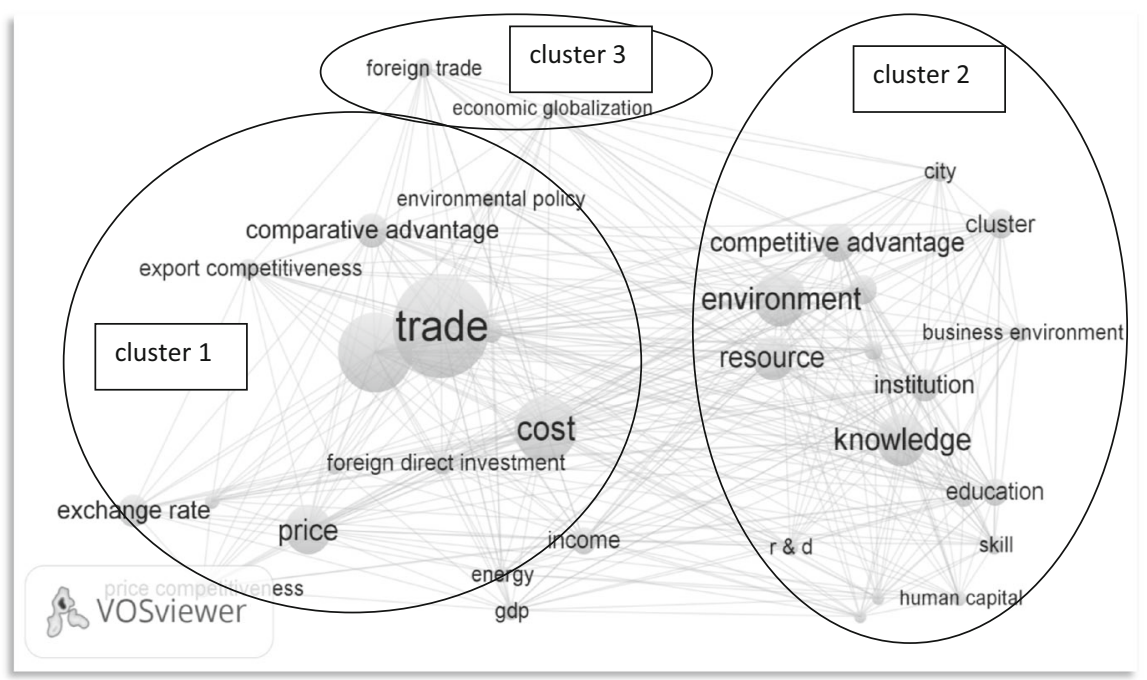

Fig. 4 Four clusters in the international competitiveness literature (2003-2015) by term co-occurrence analysis. Source: Author's own elaboration using VOSviewer software 
impact of the quality of institutions and the business environment are analysed. Additionally, other key topics in recent international competitiveness studies are the relationship between environmental regulations and trade/export growth and the regional aspect of international competitiveness, with a particular emphasis on city competitiveness. It is worth noting that the network of lines between the terms in cluster 2 is much thicker than in cluster 1, which indicates that the terms grouped in the second cluster co-occur in the articles more often than those in the first.

The third cluster is a small one and consists of terms related to the globalization process and its impact on international competitiveness growth. The importance of the terms in cluster 3 , shown by the size of the circle and the line density, is less than that of those in the first two clusters.

\section{Discussion and concluding remarks}

In this study, using citations, network citation analysis, key-routes main path methodology and term co-occurrence analysis, I have investigated the growth pattern in the international competitiveness literature and identified the core journals and authors and the main paths of knowledge diffusion and topics in the international competitiveness literature in the discipline of economics. To the best of my knowledge this is one of the largest scale bibliometric studies conducted on literature reviews in economics and the first related to the international competitiveness concept.

The study concerns the theoretical debate about international competitiveness which concentrates on the lack of theoretical foundations of many of its concepts and on the lack of a generally accepted theory of international competitiveness. Traditionally, the international competitiveness concept is explained in the literature on the basis of international trade theories derived from the works of Adam Smith and David Ricardo (Krugman and Obstfeld 2003; Smit 2010). However, my results show that international competitiveness theory starts not from classical/neoclassical theories of international trade, but from models of imperfect competition (Dixit and Stiglitz's model), even though it is mostly measured using trade/export performance (Aiello et al. 2015).

Examining the knowledge structure, Dixit Stiglitz (1977) and Krugman (1979a, b, 1980) emerge at the core of the knowledge base, revealing in particular the high status of Krugman's works on imperfect competitive markets and increasing returns of scale in the knowledge diffusion of international competitiveness. It is a paradox that in the literature Krugman is often considered one of the most unrepentant opponents of international competitiveness analysis, especially at the macro level.

Five paths of knowledge diffusion have been identified, and these at the same time indicate the mainstream economic theories important to the development of international competitiveness studies: endogenous growth (paths 1 and 3), new trade theories (paths 1, 2, 3 and 5), location theory (path 4) and new economic geography theory (path 4). The concept of international competitiveness seems to be based on 
so many theories that a single generally accepted theory of international competitiveness may never be accepted.

The study has also identified the diversity of key topics within the concept analysed (see Figs. 3, 4), such as cost, price, exchange rate, income, FDI, technology, liberalization processes, environmental regulations, location, education/ human capital, productivity and regional aspects (city competitiveness). This abundance of key terms supports the eclectic approach to defining and measuring international competitiveness by combining different schools of thought and multiple measurements (Chaudhuri and Ray 1997; Banwet et al. 2002; Bhawsar and Chattopadhyay 2015). The results also confirm those of Balkyte and Tvaronaviciene (2010) that international competitiveness is not just about growth or economic performance but should take into consideration the 'soft factors' involved, such as the environment, quality of life, technology, knowledge, etc.

The results indicate that the importance of research domains has changed over time. Initially, there was a dominance of publications analysing the impact of price and non-price determinants (Arbatli 2016; Tsen 2016), based on international trade theories on export growth; in the last decade, the importance of studies where the impact of human capital, environmental regulations, location and productivity on trade flows has greatly increased. This supports the methodology of the WEF Growth Competitiveness Index, which involves weighing 112 different components (including 'soft' factors and changing the weights of the variables over time) (Schwab 2015).

The analysis also confirms the existence of two schools of thought on competitiveness at the country level. In economics, Porter's notion of country competitiveness is often rejected, which is why Porter and his publications have not turned out to be core in the analyses conducted. On the other hand, management studies support the Porter notion of competitiveness at the country level, i.e. countries, like companies, compete in international markets for their fair share of world markets.

The results of this study should be regarded as preliminary and requiring verification. It is hoped, however, that they will have an important role in discussion on the evolution of international competitiveness theory among disciples of economics. Further analyses are needed. From the methodological point of view, it would be worthwhile to carry out a more in-depth analysis of the relationship between the key research domains identified. Conducting a similar analysis by replacing the bibliometric indicator, i.e. numbers of citations, with the number of articles downloaded from databases should also be considered. This indicator is much easier to acquire and interpret, and is even considered by some scholars to be the best measure of the 'significance' of publications (Schlögl and Gorraiz 2012).

The limitations related to the nature of bibliometric are very well understood. They are related to the quality of citations (excessive, selective, secondary, negative and erroneous citations, self-citations), selection of documents and journals (exclusion of certain types of documents, changes in journal titles, spelling differences and errors, inconsistencies related to the indexing of subjects and incomplete coverage of the social sciences in web of science) (Ferreira et al. 2014a). Additionally, the database created does not index books, book chapters or textbooks 
on international competitiveness. This may be treated as the most significant constraint of bibliometric studies (Ferreira et al. 2014b). Nevertheless, some of these weaknesses have been removed by using the two additional databases and through careful verification of the bibliometric records used.

Acknowledgments This research has been conducted within a project financed by the National Science Centre (NCN), Poland (Decision Number DEC-2011/03/D/HS4/00861). Financial support from the NCN is gratefully acknowledged.

Open Access This article is distributed under the terms of the Creative Commons Attribution 4.0 International License (http://creativecommons.org/licenses/by/4.0/), which permits unrestricted use, distribution, and reproduction in any medium, provided you give appropriate credit to the original author(s) and the source, provide a link to the Creative Commons license, and indicate if changes were made.

\section{References}

Adam, D. (2002). The counting house. Nature, 415, 726-729.

Aiello, F., Bonanno, G., \& Via, A. (2015). Again the trade elasticities: Evidence from a selected sample of countries. Eurasian Business Review, 5(2), 259-287.

Amable, B., \& Verspagen, B. (1995). The role of technology in market shares dynamics. Applied Economics, 27, 197-204.

Amendola, G., Dosi, G., \& Papagni, E. (1993). The dynamics of international competitiveness. Weltwirtschaftliches Archiv, 129(3), 451-471.

Anca, H. (2008). Literature review of the evolution of competitiveness concept. http:// steconomiceuoradea.ro/anale/volume/2012/n1/004.pdf. Accessed 20 May 2015.

Anderson, J. E. (1979). A theoretical foundation for the gravity equation. The American Economic Review, 69(1), 106-116. Retrieved from, http://www.jstor.org/stable/1802501.

Anderson, J. E., \& Van Wincoop, E. (2003). Gravity with gravitas: A solution to the border puzzle. The American Economic Review, 93(1), 170-192.

Arbatli, C. E. (2016). Trade and income growth in the Ottoman Empire: Assessing the role of volatility and trend growth in terms of trade. Eurasian Economic Review, 6(2), 173-194.

Archambault, É., \& Gagné, É. (2004). The use of bibliometrics in the social sciences and humanities. Final Report. Canada: Science-Metrix.

Audretsch, D., \& Feldman, M. (1996) R\&D spillovers and the geography of innovation and production. The American Economic Review, 86(3), 630-640. Retrieved from, http://www.jstor.org/stable/ 2118216.

Balassa, B. (1964). The purchasing power parity doctrine-A reappraisal. Journal of Political Economy, 72(6), 584-596.

Balassa, B. (1965). Trade liberalization and revealed comparative advantage. Manchester School of Economic and Social Studies, 33(2), 99-123.

Balkyte, A., \& Tvaronaviciene, M. (2010) Perception of competitiveness in the context of sustainable development: facets of "sustainable competitiveness". Journal of Business Economics and Management, 11(2), 341-365.

Banwet, D. K., Momaya, K., \& Shee, H. K. (2002). Competitiveness: Perceptions, reflections and Directions. IIMB Management Review, 14(3), 105-116.

Bar-Ilan, J. (2008). Informetrics at the beginning of the 21st century-A review. Journal of Informetrics, $2,152$.

Barrett, S. (1994). Self-enforcing international environmental agreements. Oxford Economic Papers, 46(1), 878-894. doi:10.1093/oep/46.Supplement_1.878.

Batagelj, V. (2001). Pajek_program for large networks analysis and visualization. Dagstuhl seminar Link Analysis and Visualization, Dagstuhl, July 1-6. http://vlado.fmf.uni-1j.si/pub/networks/doc/ dagstuh1.01/. Accessed 23 September 2015. 
Batagelj, V. (2003). Efficient algorithms for citation network analysis. http://arxiv.org/abs/cs.DL/ 0309023. Accessed 23 September 2015.

Berger, T., \& Bristow, G. (2009). Competitiveness and the benchmarking of nations-A critical reflection. International Advances in Economic Research, 15(4), 378-392.

Bergstrand, J. H. (1989). The generalized gravity equation, monopolistic competition, and the factor proportions theory in international trade. Review of Economics and Statistics, 71(1), 143-153.

Bhawsar, P., \& Chattopadhyay, U. (2015). Competitiveness: Review, reflections and directions. Global Business Review, 16(4), 665-679.

Bofinger, P. (1995). Die internationale Wettbewerbsfaehigkeit ganzer Volkswirtschaften: Ein Phaeinomen auf der Suche nach einer Theorie [The international competitiveness of economies: a phenomenon of a theory's search]. Kredit und Kapital, 28, 467-497.

Boltho, A. (1996). The assessment: International competitiveness. Oxford Review of Economic Policy, 12(3), 1-16.

Bonilla, C., \& Merigó, J. M. (2015). Economics in Latin America: A bibliometric analysis. Scientometrics, 105(2), 1239-1252.

Bornmann, L., Mutz, R., Neuhaus, Ch., \& Daniel, H.-D. (2008). Citation counts for research evaluation: Standards of good practice for analyzing bibliometric data and presenting and interpreting results. Ethics in Science and Environmental Politics, 8(1), 93-102.

Boschma, R., \& Iammarino, S. (2009). Related variety, trade linkages, and regional growth in Italy. Economic Geography, 85(3), 289-311.

Bradford, S. C. (1985). Sources of information on specific subjects. Journal of Information Science, 10(4), 173-180.

Brander, J. A. (1985). Export subsidies and international market share rivalry. Journal of International Economics, 18, 83-100.

Bris, A., \& Caballero J. (2015). Revisiting the fundamentals of competitiveness: A Proposal. IMD Report. https://www.imd.org/uupload/imd.website/wcc/Fundamentals.pdf. Accessed 04 July 2015.

Card, D., \& DellaVigna, S. (2012) Nine facts about top journals in economics. NBER Working Paper No. 18665. Retrieved from, http://www.nber.org/papers/w18665.

Chaudhuri, S., \& Ray, S. (1997). The Competitiveness Conundrum: Literature Review and Reflections. Economic and Political Weekly, 32(48), 83-91. Retrieved from, http://www.jstor.org/stable/ 4406121.

Cho, C. H., \& Khang, H. K. (2006). The state of internet-related research in communications, marketing, and advertising: 1994-2003. Journal of Advertising, 35(3), 143-163.

Cho, D. S., Moon, H. C., \& Kim, M. J. (2008). Characterizing international competitiveness in international business research: A MASI approach to national competitiveness. Research in International Business and Finance, 22, 175-192.

Copeland, B., \& Taylor, M. S. (2004). Trade, growth, and the environment. Journal of Economic Literature, 42(1), 7-71.

De Bellis, N. (2009). Bibliometrics and citation analysis, from the science citation index to cybermetrics. Plymouth: The Scarecrow Press Inc.

De Grauwe, P. (2010). Introduction. In P. De Grauwe (Ed.), Dimensions of competitiveness. Cambridge: MIT Press.

De Solla Price, D. J. (1963). Little science, big science. New York: Columbia University Press.

Demailly, D., \& Quirion, P. (2008). European Emission Trading Scheme and competitiveness: A case study on the iron and steel industry. Energy Economics, 30(4), 2009-2027.

Dixit, A., \& Stiglitz, J. (1977). Monopolistic Competition and Optimum Product Diversity. The American Economic Review, 67(3), 297-308. Retrieved from, http://www.jstor.org/stable/1831401.

Dunning, J. H. (1993). Internationalizing Porter's Diamond. Management International Review, 33, 7-15.

Emrouznejad, A., \& Marra, M. (2014). Ordered weighted averaging operators 1988-2014. A citation based literature survey. International Journal of Intelligent Systems, 29(11), 994-1014.

Fagerberg, J. (1988). International competitiveness. The Economic Journal, 98, 355-374.

Fagerberg, J., Srholec, M., \& Knell, M. (2007). The competitiveness of nations: Why some countries prosper while others fall behind. World Development, 35(10), 1595-1620.

Ferreira, M., Pinto, C., \& Serra, F. (2014a). The transaction costs theory in international business research: A bibliometric study over three decades. Scientometrics, 98(3), 1899-1922.

Ferreira, M., Reis, N., \& Miranda, R. (2015). Thirty years of entrepreneurship research published in top journals: Analysis of citations, co-citations and themes. Journal of Global Entrepreneurship Research, 5, 17-39. 
Ferreira, M. P., Santos, J., Almeida, M., \& Reis, N. (2014b). Mergers \& acquisitions research: A bibliometric study of top strategy and international business journals, 1980-2010. Journal of Business Research, 67(12), 2550-2558.

Flanagan, R., Lu, W., Shen, L., \& Jewell, C. (2007). Competitiveness in construction: A critical review of research. Construction Management and Economics, 25, 989-1000.

Freeman, C. (2004). Technological infrastructure and international competitiveness. Industrial and Corporate Change, 13(3), 541-569.

Fujigaki, Y. (1998). Filling the gap between the discussions on science and scientists' everyday activities: Applying the autopoiesis system theory to scientific knowledge. Social Science Information, 37(1), 5-22.

Fujita, M., \& Krugman, P. (2003). The new economic geography: Past, present and the future. Papers in Regional Science, 83(1), 139-164.

Garfield, E. (1955). Citation indexes for science: a new dimension in documentation through associations of ideas. http://www.garfield.library.upenn.edu/pub.html. Accessed 11 June 2015.

Garfield, E. (1979). Citation Indexing, its theory and application in Science, Technology and Humanities. Philadelphia: Wiley.

Garfield, E. (2007). The evolution of the science citation index. International Microbiology, 10(1), 65-69.

Garfield, E., Malin, M.V., Small, H. (1978). Citation data as science indicators. In: Y. Elkana, J. Lederberg, R. K Merton, A. Thackray, \& H. Zuckerman (Eds.), Toward a metric of science: the advent of science indicators (pp. 179-207). New York: Wiley.

Garfield, E., Paris, S., \& Stock, W. G. (2006). HistCite ${ }^{\mathrm{TM}}$ : A software tool for informetric analysis of citation linkage. Information Wissenschaft \& Praxis, 57(8), 391-400.

Garfield, E., Pudovkin, A. I., \& Istomin, V. S. (2003). Why do we need algorithmic historiography? Journal of the American Society for Information Science and Technology, 54(5), 400-412.

Garfield, E., Sher, I. H., \& Torpie, R. J. (1964). The Use of Citation Data In Writing the History of Science. Philadelphia: Institute for Scientific Information Inc.

Gkypali, A., Rafailidis, A., \& Tsekouras, K. (2015). Innovation and export performance: do young and mature innovative firms differ? Eurasian Economic Review, 5(2), 397-415.

Greaker, M. (2003). Strategic environmental policy when the governments are threatened by relocation. Resource and Energy Economics, 25(2), 141-154.

Greenhalgh, C. (1990). Innovation and trade performance in the UK. Economic Journal, 100, 105-118.

Griffith, B. C., Small, H. G., Stonehill, J. A., \& Dey, S. (1974). The structure of scientific literatures II: Toward a macro- and micro-structure for science. Science Studies, 4(4), 339-365.

Hassett, K. A. (Ed.). (2012). Rethinking competitiveness. Washington: The AEI Press.

Helgeson, H. C., Murphy, W. M., \& Aagaard, P. (1984). Thermodynamic and kinetic constraints on reaction rates among minerals and aqueous solutions. II. Rate constants, effective surface area, and the hydrolysis of feldspar. Geochimica et Cosmochimica Acta, 48, 2405-2432.

Hummon, N. P., \& Doreian, P. (1989). Connectivity in a citation network: The development of DNA theory. Social Networks, 11, 39-63.

Hung, S. C., Liu, J. S., Lu, L. Y. Y., \& Tseng, Y. C. (2014). Technological change in lithium iron phosphate battery: the key-route main path analysis. Scientometrics, 100, 97-120.

ITS Global Report. (2008). Improving International Competitiveness in Australian Business. https://dfat. gov.au/trade/topics/review-of-export-policies-programs/Documents/BCAAttachmentB.pdf. Accessed 1 September 2015.

Jaffe, A. B., Trajtenberg, M., \& Henderson, R. (1993). Geographic localization of knowledge spillovers as evidenced by patent citations. The Quarterly Journal of Economics, 108(3), 577-598.

Kennedy, P. (1994). Equilibrium pollution taxes in open economies with imperfect competition. Journal of Environmental Economics and Management, 27, 49-63.

Koskinen, J., Isohanni, M., Paajala, H., Jääskeläinen, E., Nieminen, P., Koponen, H., et al. (2008). How to use bibliometric methods in evaluation of scientific research? An example from Finnish schizophrenia research. Nordic Journal of Psychiatry, 62(2), 136-143.

Krugman, P. (1979a). Increasing returns, monopolistic competition and international trade. Journal of International Economics, 9(4), 469-479.

Krugman, P. (1979b). A Model of Innovation, Technology Transfer, and the World Distribution of Income. Journal of Political Economy, 87(2), 253-266.

Krugman, P. (1980). Scale economies, product differentiation, and the pattern of trade. The American Economic Review, 70(5), 950-959.

Krugman, P. (1990). Rethinking International Trade. Cambridge, MA: MIT Press. 
Krugman, P. (1991). Increasing returns and economic geography. Journal of Political Economy, 99, 483-499.

Krugman, P. (1992). Does the new trade theory require a new trade policy? World Economy, 5(4), 423-442.

Krugman, P. (1994). Competitiveness-A dangerous obsession. Foreign Affairs 73(2), $28-44$.

Krugman, P. (2011). Competitiveness. http://krugman.blogs.nytimes.com/2011/01/22/competitiveness/?_ $\mathrm{r}=0$. Accessed 08 January 2015.

Krugman, P., \& Obstfeld, M. (2003). International economics: Theory and policy (4th ed.). New York: Harper Collins.

Kulkarni, A. V., Aziz, B., Shams, I., \& Busse, J. W. (2009). Comparisons of citations in Web of Science, Scopus, and Google Scholar for articles published in general medical journals. JAMA, 302, 1092-1096.

Kumar, A., Shivarama, J., Choukimath, P.A. (2015). Popular scientometric analysis, mapping and visualisation softwares: An overview. http://hdl.handle.net/1944/1855. Accessed 11 May 2015.

Lachmann, W. (2001). Improving the international competitiveness of nations. WEP Working Paper, 6, $1-21$.

Liu, J. S., \& Lu, L. Y. Y. (2012). An integrated approach for main path analysis: development of the Hirsch index as an example. Journal of the American Society for Information Science and Technology, 63(3), 528-542.

Lotka, A. J. (1926). The frequency distribution of scientific productivity. Journal of the Washington Academy of Sciences, 16(2), 317-324.

Lucio-Arias, D. (2010). Modelling and measuring the dynamics of scientific communication. $\mathrm{PhD}$ Thesis, http://dare.uva.nl/document/2/78811. Accessed 17 September 2015.

Lucio-Arias, D., \& Leydesdorff, L. (2008). Main-path analysis and path-dependent transitions in HistCite $^{\mathrm{TM}}$-based historiograms. Journal of the American Society for Information Science and Technology, 59(12), 1948-1962.

Lundberg, J. (2006). Bibliometrics as a research assessment tool-impact beyond the impact factor. Stockholm: Karolinska Institutet.

Markusen, J., \& Rutherford, T. (1993). Discrete plant-location decisions in an applied generalequilibrium model of trade liberalization. Weltwirtschaftliches Archiv, 130(1), 133-151.

Melitz, M. J. (2003). The impact of trade on intra-industry reallocations and aggregate industry productivity. Econometrica, 71(6), 1695-1725.

Merigó, J. M., Gil-Lafuente, A. M., \& Yager, R. R. (2015a). An overview of fuzzy research with bibliometric indicators. Applied Soft Computing, 27, 420-433.

Merigó, J. M., Mas-Tur, A., Roig-Tierno, N., \& Ribeiro-Soriano, D. R. (2015b). A bibliometric overview of the Journal of Business Research between 1973 and 2014. Journal of Business Research, 68, 2645-2653.

Mitschke, A. (2008). The influence of national competition policy on the international competitiveness of nations: A contribution to the debate on international competition rules. Heidelberg: Springer.

Montobbio, F. (2003). Sectoral patterns of technological activity and export market share dynamics. Cambridge Journal of Economics, 27(4), 523-545.

Montobbio, F., \& Rampa, F. (2005). The impact of technology and structural change on export performance in nine developing countries. World Development, 33(4), 527-547.

Neary, J. P. (2006). International trade and the environment: Theoretical and policy linkages. Environmental \& Resource Economics, 33(1), 95-118.

Nooy, W. D., Mrvar, A., \& Batagelj, V. (2005). Exploratory network analysis with Pajek. Cambridge: Cambridge University Press.

Pincus, H. A., Henderson, B., Blackwood, D., \& Dial, T. (1993). Trends in research in two general psychiatric journals in 1969-1990: Research on research. American Journal of Psychiatry, 150(1), 135-142.

Porter, M. E. (1990). The competitive advantage of nations. London: MacMillan.

Porter, M. E., \& Van der Linde, C. (1995). Toward a new conception of the environmentCompetitiveness relationship. Journal of Economic Perspectives, 9, 97-118.

Price, D. J. (1951). Quantitative measures of the development of science. Archives Internationales D'histoire Des Sciences Journal, 4, 85-93.

Pritchard, A. (1969). Statistical bibliography or bibliometrics? Journal of Documentation, 25(4), 348-349. 
Rutkauskas, A. (2008). On the sustainability of regional competitiveness development considering risk. Technological and Economic Development of Economy, 14(1), 89-99.

Schlögl, Ch., \& Gorraiz, J. (2012). Sind Downloads die besseren Zeitschriftennutzungsdaten? Ein Vergleich von Download- und Zitationsindikatoren [Are downloads the best indicators of journals importance? A comparison of download and citation indicators]. Zeitschrift für Bibliothekswesen und Bibliographie, 59(2), 87-95.

Schwab, K. (2015). The Global Competitiveness Report 2014-2015. Retrieved from http://www. weforum.org. Accessed 22 Jan 2015.

Simmie, J. (2003). Innovation and urban regions as national and international nodes for the transfer and sharing of knowledge. Regional Studies, 37(6-7), 607-620.

Small, H. (1973). Co-citation in the scientific literature: A new measure of the relationship between two documents. Journal of the American Society for Information Science, 24(4), 265-269.

Small, H. (1999). Visualizing science by citation mapping. Journal of the American Society for Information Science, 50(9), 799-813.

Smit, A. J. (2010). The competitive advantage of nations: is Porter's Diamond Framework a new theory that explains the international competitiveness of countries? Southern Africa Business Review, 14(1), 105-130.

Soete, L. L. G. (1981). A general test of the technological gap trade theory. Weltwirtschaftliches Archiv, $117,638-666$.

Spence, A. M., \& Hazard, H. A. (Eds.). (1988). International competitiveness. Cambridge: Ballinger Publishing Company.

Srivastava, D., Shah, H., \& Talha, M. (2006). Determinants of competitiveness in Indian public sector companies: An empirical study. Competitiveness Review, 16(3), 212-222.

Teixeira, A., \& Sequeira, J. (2009). Determinants of the international influence of a R\&D organisation: A bibliometric approach. European Journal of Scientific Research, 53(3), 400-430.

Tobey, J. (1990). The effect of domestic environmental policies on patterns of word trade-An empirical test. Kyklos, 43(2), 191-209.

Tsen, W. H. (2016). Exchange rate volatilities and disaggrated bilaterial exports of Malaysia to the United Stated: Empirical evidence. Eurasian Economic Review, 6(2), 289-314.

Tu, J. N., \& Hsu, S. (2015). Constructing conceptual trajectory maps to trace. The development of research fields. Journal of the Association for Information Science and Technology. doi:10.1002/asi. 23522.

Van Beers, C., \& Van den Bergh, J. C. J. M. (1997). An empirical multi-country analysis of the impact of environmental regulations on foreign trade flows. Kyklos, 50, 29-46.

Van Eck, N.J. (2011). Methodological Advances in Bibliometric Mapping of Science. Phd thesis. http:// www.erim.eur.nl/centres/business-intelligence/news/detail/1992-phd-thesis-defense-nees-jan-vaneck-on-methodological-advances-in-bibliometric-mapping-of-scien/. Accessed 07 September 2015.

Van Eck, N. J., Frasincar, F.,Van den Berg, J. (2006). Visualizing concept associations using concept density maps. In Proceedings of the 10th international conference on information visualisation (pp. 270-275). IEEE Computer Society.

Van Eck, N. J., \& Waltman, L. (2007). Bibliometric mapping of the computational intelligence field. International Journal of Uncertainty, Fuzziness and Knowledge-Based Systems, 15(5), 625-645.

Van Eck, N. J., \& Waltman, L. (2010). Software survey: VOSviewer, a computer program for bibliometric mapping. Scientometrics, 84(2), 523-538.

Van Eck, N. J., \& Waltman, L. (2011). Text mining and visualization using VOSviewer. ISSI Newsletter, 7(3), 50-54.

Van Eck, N. J., Waltman, L., Noyons, E., \& Buter, R. K. (2010). Automatic term identification for bibliometric mapping. Scientometrics, 82(3), 581-596.

Vernon, R. (1966). International investment and international trade in the product cycle. The Quarterly Journal of Economics, 80(2), 190-207.

Verspagen, B. (2007). Mapping technological trajectories as patent citation networks: A study on the history of fuel cell research. Advances in Complex Systems, 10(1), 93-115.

Williams, B. C., \& Plouffe, C. R. (2007). Assessing the evolution of sales knowledge: A 20-year content analysis. Industrial Marketing Management, 36(4), 408-419.

Yale, L., \& Gilly, M. C. (1988). Trends in advertising research: A look at the content of marketingoriented journals from 1976 to 1985. Journal of Advertising, 17(1), 12-22. 
Yang, K., \& Meho, L. (2007). Impact of data sources on citation counts and rankings of LIS faculty: Web of Science versus Scopus and Google Scholar. Journal of the American Society for Information Science and Technology, 58(13), 2105-2125.

Zhao, D., \& Strotmann, A. (2015). Analysis and visualization of citation network. In G. Marchionini (Ed.) Synthesis lectures on information concepts retrieval and services. Morgan \& Claypool Publishers.

Zipf, G. K. (1949). Human behavior and the principle of least effort. Cambridge: Addison-Wesley. 